Molecular Biology of the Gene is a celebration of the crowning achievements of biology during the second half of the twentieth century.

So what is left to do? What problems remain for the fifth edition? Since the end of the nineteenth century biologists have sought a unified theory explaining what is special about the organization of living matter, how that organization is inherited, how it develops within the individual and how it evolves with time. These volumes display the great success of molecular biology in clarifying the first two areas. If the key to development is differential gene expression, as many believe, prorapid, if not explosive. Each day we hear exciting new information about gene regulation, how proteins interact with DNA to gress in the third area should now be

turn genes on and off or up and down, and how growth factors, hormones and other extrinsic molecules regulate this activity.

In the fourth area - evolution molecular biology will provide new arguments about prebiotic evolution and the origin of cells; and as DNA sequencing becomes ever easier, evolutionists will infer much about the past history of genomes from their present-day sequences. Thus we can confidently predict larger sections on developmental biology and genome evolution in the next edition of Molecular Biology of the Gene. In the meantime, these two volumes give us much to feast upon.

Joseph G. Gall is American Cancer Society Professor of Developmental Genetics, Carnegie Institution, 115 West University Parkway, Baltimore, Maryland 21210, USA.

\section{Instruments of change}

\section{Carole Stott}

Early Scientific Instruments: Europe 1400-1800. By Anthony Turner. Philip Wilson-Sotheby's/Harper \& Row: 1987. Pp. 320. £55, \$100.

The Divided Circle: A History of Instruments for Astronomy, Navigation and Surveying. By J.A. Bennett. PhaidonChristie's/Salem House: 1987. Pp. 224. $£ 45, \$ 75$.

THE art world is becoming interested in scientific instruments. Auction prices haven't yet reached the impressionist level; the most coveted pieces are guaranteed only to reach a six-figure sum. But the dealers and auction houses have a glint in their eye and can see the way forward. Sale catalogues describe the material and mode of manufacture of instruments, rather than their function. The fact that a particular device would be pretty well useless and was only produced to adorn a gentleman's study does not lower the price. The more modern the instrument, the cheaper it is, not only because oldequals-value, but because the instruments of the nineteenth and twentieth centuries are functional and look functional.

Scientific instruments are not as old as science itself, and it was only in the sixteenth century that they began to be made in any number. These two volumes have both been published by leading auction houses which are keen to open up the subject to new customers, collectors who are equally capable of raising auction prices and affording expensive books.

Between them, the authors have 40 years of experience as historians, collectors and custodians of eminent museum collections. Their books are lavishly illustrated, drawing examples almost ex-

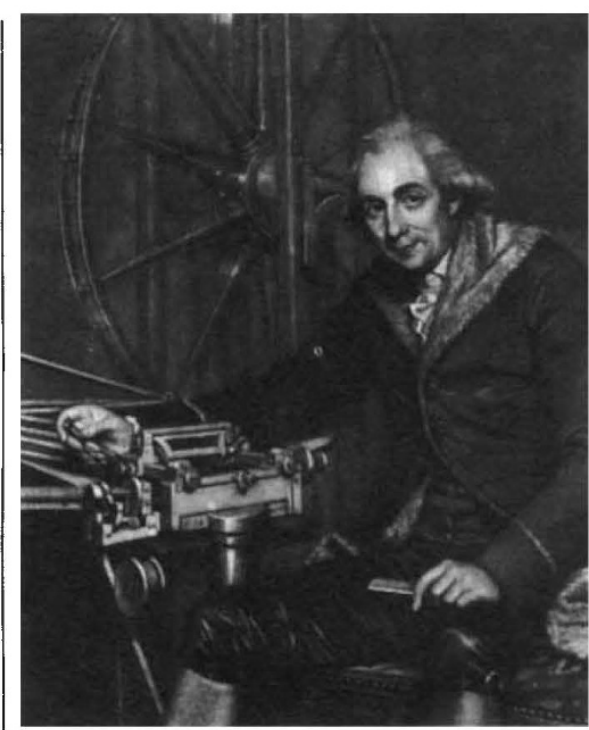

Divide and rule - Jesse Ramsden holding the old tools of his trade, but with his arm on the new dividing engine which drastically reduced the time and cost of graduating a scale.

clusively from European collections, and their choices of material reflect the geographical areas of original production and of present-day interest. Turner takes his collections, Bennett is more firmly based in Britain. The result is that there is little overlap between the books though both provide excellent catalogues of extant instruments. The catalogues, however, are a by-product of the authors' aims, which are to describe the instruments and their development against the intellectual and social background of the time.

Turner's was perhaps the more daunting task. He has chosen to cover all types of scientific instrument, though it soon becomes clear that medical and associated instruments and chemical apparatus are excluded. But he does include many types which are not to be found in Bennett's book, the telescope, microscope, barometer and thermometer for example. Some of these instruments, however, are examples from private and continental introduced as if the reader knows already exactly what they are and how they work. Thus there is no clear explanation of the style or mode of construction of a Gregorian telescope, whereas the astrolabe is dissected, laid out in its parts and labelled thoroughly. This latter approach could have been used effectively throughout the book. Further evidence of Turner's assumption of scientific sophistication on the part of his audience is the sequence of four photographs of hair hygrometers, three of which lack their essential hairs and are therefore completely unusable.

Bennett concentrates on the anglemeasurement instruments used in astronomy, navigation and surveying. He looks at three historical periods in the course of the book: the early modern period, and then the eighteenth and nineteenth centuries. The technique is the same, whatever the subject or period. The author lucidly describes the state of the science and the social context of the time. The leading advocates, the books of influence and the instruments themselves are discussed alongside photographs of extant examples. Nor are the instrument makers and their craft forgotten. Bennett tells the story of the pre-eminence of the English maker in the eighteenth century, men such as Dollond, Ramsden and Troughton, all Royal Society Copley Medal winners, who by the time of the Great Exhibition in 1851 had relinquished much of their position and trade to European manufacturers.

There it ends, however. We are told very little of how any of the instruments work and of the scientific principles behind them. The only attempt at this is in the first few pages of the book, where there is an explanation of right ascension and declination, but without any accompanying diagram and so conjuring up the image of a Frenchman trying to describe a spiral staircase with his hands in his pockets. Matters of instrumental accuracy and performance are also ignored. How easy was it to divide a circle? And how do a vernier scale and Ramsden's dividing engine, which "was to revolutionise the manufacture of portable instruments", actually work? We are left in the dark on such questions.

Both volumes contain an enormous amount of well-researched and wellpresented information. Turner's notes and both bibliographies are excellent springboards for further investigation. Books on scientific instruments are scarce, and these two are valuable additions to the library of any serious collector and dealer. But there is plenty of room for authors to tackle the fascinating subject of the science behind the hardware.

Carole Stott is Curator of Astronomy at the Old Royal Observatory, National Maritime Museum, Greenwich, London SE10 9NF, UK. 